\title{
Haemochromatosis gene mutations in a clustered Italian population: evidence of high prevalence in people of Celtic ancestry
}

\author{
Gabriele Pozzato ${ }^{1}$, Francesca Zorat ${ }^{1}$, Fabiana Nascimben ${ }^{1}$, Michela Gregorutti ${ }^{1}$, \\ Consuelo Comar ${ }^{1}$, Stefano Baracetti ${ }^{1}$, Serena Vatta ${ }^{2}$, Elena Bevilacqua ${ }^{3}$, Anna Belgrano ${ }^{3}$, \\ Sergio Crovella ${ }^{3}$ and Antonio Amoroso ${ }^{* 2,3}$
}

\author{
${ }^{1}$ Dipartimento di Medicina Clinica \& Neurologia, Unità Operativa Medicina Clinica, Università degli Studi di \\ Trieste, Trieste, Italy; ${ }^{2}$ Servizio di Genetica Medica, Istituto per l'Infanzia, Trieste, Italy; ${ }^{3}$ Dipartimento di Scienze \\ della Riproduzione e dello Sviluppo, Sezione di Genetica, Università degli Studi di Trieste, Trieste, Italy
}

Hereditary haemochromatosis is an inherited disorder characterised by an excessive iron absorption from the diet and is associated with several HFE gene mutations. One hypothesis is that these genetic mutations originated in the Celtic populations. The aim of this study is to determine the frequency of HFE gene mutations in a clustered Italian population of Celtic ancestry (Cimbri, Asiago plateau). One hundred and forty-nine consecutive unrelated blood donors (31 females and 118 males) were enrolled in this study. A family investigation was performed in each case to identify the ethnic origin of the individuals. The analysis of HFE gene mutations was performed by PCR amplification followed by digestion with Rsal and Dpnll restriction enzymes. At least one HFE gene mutation was identified in 49 individuals (32.9\%) of the studied population. The allele frequencies of the $\mathrm{C} 282 \mathrm{Y}$ and H63D were respectively 0.037 and 0.144 . When we considered only the 103 individuals with relatives born in Asiago, the prevalence of the HFE mutations rose from 32.9 to $39.8 \%$; the allele frequencies of the $\mathrm{C} 282 \mathrm{Y}$ and $\mathrm{H} 63 \mathrm{D}$ were respectively 0.048 and 0.174 . The mean serum iron and ferritin levels were significantly higher in individuals with the HFE mutations than in normal cases. This study indicates that the prevalence of the HFE gene mutations is surprisingly high in Italians with Celtic ancestry. This could suggest the need to perform large mass studies in selected areas of the country to detect the affected patients and prevent the disease in homozygous individuals. European Journal of Human Genetics (2001) 9, 445-451.

Keywords: haemochromatosis; HFE mutations; Celtic people

\section{Introduction}

Hereditary haemochromatosis (HHC) is an inborn disorder of iron metabolism, inherited as an autosomal-recessive trait. The disease is characterised by an excessive absorption of dietary iron and by a progressive storage of iron in several organs such as the liver, pancreas, pituitary gland and heart. ${ }^{1}$ If untreated, the storage of iron results in end-organ damage

*Correspondence: A Amoroso, MD, Servizio di Genetica, Istituto per I'Infanzia, Via dell'Istria 65/1, 34137 Trieste, Italy.

Tel: +39040 3785275; Fax: +39 040 3785210;

E-mail: amoroso@burlo.trieste.it

Received 6 July 2000; revised 5 February 2001; accepted 27 February 2001 and leads to liver cirrhosis (and hepatocellular carcinoma), diabetes, cardiac failure, hypogonadysm, arthritis and reduced life expectancy. ${ }^{2}$

The recent identification of the HHC gene (known as HFE) ${ }^{3}$ has important implications for diagnosis and screening. Two mutations in the HFE gene are associated with HHC: a cysteine to tyrosine mutation at amino acid $282(\mathrm{C} 282 \mathrm{Y})$ and a histidine to aspartate at amino acid 63 (H63D). ${ }^{4}$ Whereas the $\mathrm{C} 282 \mathrm{Y}$ mutation is proven to be related to the disease (from 80 to $100 \%$ of affected patients are homozygous for this mutation), the implication of $\mathrm{H63D}$ is less clear. ${ }^{5}$ A small number of patients with HHC were identified as homozygous for $\mathrm{H} 63 \mathrm{D}$ or as compound heterozygous H63D/C282Y. ${ }^{6}$ 
Unfortunately, in many patients $(13-20 \%)$ with histologically proven $\mathrm{HHC}$, neither one of these mutations could be identified. ${ }^{7,8}$

Multiple studies have suggested that HHC is a disease with a prevalence of two to eight cases per 1000 in the Caucasoid population. ${ }^{9-11}$ It seems that the genetic mutations originally occurred in the Celtic populations and that genetic markers for HHC could be a genetic tracer of the migratory pattern of these peoples. ${ }^{12}$ In fact, several studies have shown a high prevalence of a HFE mutation in Northern European populations, ${ }^{13-15}$ whereas in those of the Mediterranean basin the prevalence seems low. ${ }^{16,17}$ The HFE gene mutations are almost absent in Far-East countries. ${ }^{18,19}$ The typical Celtic mutation is the C282Y, usually found in the ancestral haplotype carrying the HLA-A3 allele and the D6S105 allele $8 .^{20}$

In Italy, many authors have reported the prevalence of the HFE mutation pattern of high-risk groups ${ }^{21,22}$ and of general population: ${ }^{16}$ unfortunately the ethnic origin of the sample was often omitted. To overcome this problem, we have performed a screening survey in a clustered Italian population with possible Celtic ancestry.

\section{Materials and methods Study population}

The investigation took place in the Asiago plateau (Latitude: 45.8758, Longitude: 11.5083), situated in Veneto, one of the Italian regions (http://www.ascom.vi.it/asiago/home pagein.htm). The Asiago plateau counts 7000 inhabitants. The indigenous population, named 'Cimbri', was an ancient tribe of Celtic ancestry who settled on the plateau around the 2nd century BC. Unpaid voluntary blood donors were selected as study population from this group.

Over a period of 4 months, 149 consecutive unrelated blood donors (31 females and 118 males, mean age \pm SD: $36 \pm 11$ years) were recruited for this study. A family investigation was performed in each case to identify the ethnic origin of the individuals. Informed consent was obtained from all volunteers and the protocol was approved by the Ethical Committee of the Asiago General Hospital and the Blood Donors Volunteer Association (Section of Asiago).

\section{Laboratory investigation}

Liver function tests as well as haematological parameters were determined using the standard laboratory methods. Serum iron was analysed by the use of a spectrophotometer in a centrifugal analyser (Hoffman la Roche, Basel, Suisse) with a guanidinium ferrozine solution. Serum transferrin was measured by immunoturbidimetry using antibodies provided by Dako (Copenhagen, Denmark). The degree of transferrin saturation was calculated by dividing serum iron value by the total iron binding capacity and then multiplied by 100 . The serum ferritin was measured using a sandwich radioimmunoassay (Bio-Rad, Milan, Italy) with a NE 1600 gamma counter.

Anti-HCV antibodies were assayed by the immunoenzymatic screening test ORTHO-HCV (Ortho Diagnostic Systems, Raritan, NJ, USA) of the second-generation. Hepatitis B virus (HBV) and human immunodeficiency virus (HIV) markers were detected by an enzyme-linked immunosorbent assay (ELISA) using commercially available kits (Abbott Laboratories, North Chicago, IL, USA).

\section{Analysis of HFE gene mutations}

The DNA was extracted from peripheral blood and stored at $-20^{\circ} \mathrm{C}$ for the HFE gene analysis. Amplifications were performed in a $50 \mu \mathrm{l}$ volume containing $20 \mathrm{pmol}$ of each primer (C282Y F: 5'-TGGCAAGGGTAAACAGATCC-3'; C282Y R: 5'-CTCAGGCACTCCTCTCAACC-3' and H63D F: 5'ACATGGTTAAGGCCTGTTGC-3'; H63D R: 5'-GCCACATCTGGCTTGAAATT-3'), $200 \mu \mathrm{mol}$ of each deoxyribonuclotide, $10 \times$ PCR buffer (PE Biosystems, Foster City, CA, USA), $1.5 \mathrm{mmol} \mathrm{MgCl}_{2}$ and $1 \mathrm{U}$ AmpliTaq Gold DNA polymerase (PE Biosystems). The cycling conditions were: an initial hold at $95^{\circ} \mathrm{C}$ for $12 \mathrm{~min}$, then 35 cycles at $95^{\circ} \mathrm{C}$ for $1 \mathrm{~min}, 62^{\circ} \mathrm{C}$ for $1 \mathrm{~min}$ and $72^{\circ} \mathrm{C}$ for $1 \mathrm{~min}$ in the GeneAmp PCR system 9700 thermal cycler (PE Biosystems).

After amplification, aliquots $(10 \mu \mathrm{l})$ of the PCR mixture were digested overnight at $37^{\circ} \mathrm{C}$ with $R s a \mathrm{I}(\mathrm{C} 282 \mathrm{Y})$ and $D p n \mathrm{II}$ (H63D) restriction enzymes, using the restriction buffer recommended by the manufacturer (Celbio s.r.l., Milan, Italy). The resulting fragments were electrophoresed on a 3\% MetaPhor agarose gel (FMC BioProducts, Rockland, ME, USA) and observed under UV illumination after ethidium bromide staining. In normal controls the RsaI digestion of the $389 \mathrm{bp}$ PCR products (encompassing codon 282) produced two fragments of 249 and $140 \mathrm{bp}$; in homozygous mutants, it produced three: 249,111 and 29 bp; in heterozygotes four: 249, 140, 111 and 29 bp.

Since the H63D mutation abolishes the DpnII restriction site, ${ }^{4,23}$ in the presence of a wild-type genotype we obtained after DpnII digestion of the 208 bp PCR product (encompassing codon 63) two fragments of 138 and $70 \mathrm{bp}$; in homozygous mutants one 208 bp fragment only; in heterozygotes three fragments of 208, 138 and $70 \mathrm{bp}$.

\section{Analysis of D6S105 and of HLA-A3 polymorphisms} D6S105 polymorphism was analysed as previously described. ${ }^{24}$ Briefly, PCR amplifications were performed in a $25 \mu \mathrm{l}$ reaction containing 5 pmoles of each primer, $100 \mu$ moles of each deoxiribonucleotide, $10 \times$ PCR buffer (PE Biosystems), $0.75 \mathrm{mmol} \mathrm{MgCl}_{2}, 1 \mathrm{U}$ AmpliTaq Gold DNA Polymerase (PE Biosystems). The samples were processed through 35 temperature cycles consisting of $1 \mathrm{~min}$ at $95^{\circ} \mathrm{C}$, $2 \mathrm{~min}$ at $52^{\circ} \mathrm{C}, 1 \mathrm{~min}$ at $72^{\circ} \mathrm{C}$ in the gene Amp PCR System 9700 Thermalcycler (PE Biosystems). D6S105 alleles were detected and analysed on an automated ABI Prism 310 Genetic Analyzer (PE Biosystems). 
HLA-A3 typing was performed by ARMS-PCR with the following HLA-A3 specific primers (provided by Carlo Carcassi, University of Cagliari, Italy): F: 5'-AGCGACGCCGCGAGCCA-3' and R: 5'-CACTCCACGCACGTGCCA-3'. A 626 bp PCR product was obtained in HLA-A3 positive individuals, after amplification in $13 \mu$ l volume, using $0.1 \mu \mathrm{g}$ DNA and $0.25 \mathrm{U}$ AmpliTaq Gold DNA Polymerase (PE Biosystems). A monomorphic control fragment of 256 bp of HLA region was also specifically amplified in each reaction.

\section{Statistical analysis}

Demographic parameters and biochemical parameters were compared with the HFE genotype using the $\chi^{2}$ or $t$-test as recommended. Allelic frequencies were calculated using direct gene counting and Hardy-Weinberg equilibrium was tested by the Chi-square test using TFPGA version 1.3 software.

The migration rate $(v)$ and the density of surnames $(\alpha)$ of our sample was obtained considering the logarithmic distribution by Fisher, where $\mathrm{N}$ was the total number of individuals from Asiago, and $\mathrm{S}$ was the number of surnames found in this population. ${ }^{25}$ The $\alpha$ values have been calculated as follows: $\alpha=\mathrm{N}^{*} v / 1-v$. In order to compare $v$ values from populations of different size, we calculated $v$ by the formula $v=\alpha /(\mathrm{Pm}+\alpha)$, where $\mathrm{Pm}$ is the male census size of Asiago (3248 males). ${ }^{25}$

Frequencies of haplotypes from population were calculated using the Arlequin 2.0 software.

\section{Results}

HFE genotypes and mutation frequencies

Among the enrolled individuals, one was homozygous $(0.7 \%)$ and nine heterozygotes $(6 \%)$ for the $\mathrm{C} 282 \mathrm{Y}$ mutation. Four were homozygous for the H63D mutation (2.7\%) and 35 were heterozygotes (23.5\%). No compound heterozygotes (C282Y/H63D) were found.

In all, 49 cases (32.9\%) carried at least one of the HFE gene mutations. There were no differences in genotype frequency between males and females.

The allele frequencies of the $\mathrm{C} 282 \mathrm{Y}$ and $\mathrm{H} 63 \mathrm{D}$ mutations in this population were respectively 0.037 and 0.144 . No differences were found between the observed and the expected genotype frequencies.

We were able to determine the prevalence of the HFE mutation in those individuals selected on the basis of ethnic origin. Only a subgroup of the 149 investigated donors had parents or grandparents born outside of the Asiago plateau. We omitted those with one or more parents or grandparents born elsewhere and we selected 103 individuals for further analyses: interestingly enough, no carrier of the $\mathrm{C} 282 \mathrm{Y}$ mutation was eliminated, on the other hand, we could include only a fraction of the H63D heterozygous individuals. The frequency of the HFE mutations were significantly higher in the selected group of individuals of Celtic origin. As a matter of fact, the homozygous and heterozygous cases for $\mathrm{C} 282 \mathrm{Y}$ rose respectively to 1 and $7.7 \%$. In the same way, the prevalence of homozygous or heterozygous cases for H63D rose respectively to 3.9 and $27.4 \%$. Substantially, the overall prevalence of HFE gene mutations in this selected population rose from 32.9 to $39.8 \%$. Therefore, the allele frequencies of the C282Y and H63D mutations were respectively, 0.048 and 0.174 . The analysed population appeared within the HardyWeinberg equilibrium.

\section{Extended haplotypes carrying the HFE mutations}

The analysis of the ancestral haplotypes was performed in 100 out of 103 autochthonous individuals. The full ancestral haplotype carrying the $\mathrm{C} 282 \mathrm{Y}$ HFE mutation is characterised by the allele A3 at HLA-A locus and the allele 8 at D6S105 locus. Moreover, we defined ancestral also those haplotypes carrying at D6S105 locus the allele 7 and 9, differing from the allele 8 by 2 pairs only; this may be retraceable to the slippage mechanism, which can generate new alleles at dinucleotide microsatellites. Among the nine individuals positive for C282Y mutation, four carried the ancestral haplotype; the remaining five showed a partial ancestral haplotype because were found positive for the allele 7/8/9 at D6S105 locus but negative for HLA-A3. The frequency of the ancestral haplotype was 0.01181, while that of the partial ancestral haplotype lacking A3 was 0.01783 .

Among the 91 individuals negative for $\mathrm{C} 282 \mathrm{Y}, 12$ were also A3-positive: seven of them were also found positive for alleles 7/8/9 at D6S105 locus (haplotype frequency: 0.02619) and five negative (haplotype frequency: 0.02519).

The C282Y mutation was significantly more frequent in individuals with both HLA-A3 and the alleles 7/8/9 at D6S105 locus (four out of 11:36\%) than in those individuals without (five out of 89: $5.6 \%, P: 0.0008$ ).

\section{HFE genotype and iron indices}

The mean serum iron, ferritin concentration, and trasferrin saturation are indicated in Table 1. Despite the large number of phlebotomies, the mean serum $( \pm S D)$ iron level was significantly higher in individuals with a $\mathrm{C} 282 \mathrm{Y}$ mutation $(135.9 \pm 57.2 \mu \mathrm{g} / \mathrm{dl})$ or with a H63D mutation $(127.7 \pm 42.8 \mu \mathrm{g} / \mathrm{dl})$ than in normal cases $(116 \pm 40 \mu \mathrm{g} / \mathrm{dl}$, $P<0.03$ and 0.04 respectively). However, the mean iron serum concentration in females did not differ from that in males $(113.2 \pm 33.7 v s 117.4 \pm 42 \mu \mathrm{g} / \mathrm{dl}, P$ : N.S. $)$.

Also the mean ferritin serum concentration was significantly higher $(P<0.001)$ in the individuals with $\mathrm{C} 282 \mathrm{Y}$ mutations than in normal cases $(171 \pm 139 v s 63 \pm 67 \mu \mathrm{g} / \mathrm{l})$. In contrast, the carriers of the H63D mutations showed a normal mean serum ferritin concentration (78 $\pm 89 v \mathrm{~s}$ $63 \pm 67 \mu \mathrm{g} / \mathrm{dl}, P:$ N.S.). None of the individuals with C282Y mutations, and only one case $(2.6 \%)$ with the H63D mutations had an abnormal level of serum ferritin $(<15 \mu \mathrm{g} / \mathrm{dl})$; a large proportion of normal individuals 
Table 1 HFE mutations and mean iron indexes for the study population

\begin{tabular}{|c|c|c|c|c|c|}
\hline $\begin{array}{l}\text { HFE genotypes in } 149 \\
\text { analysed individuals (number) }\end{array}$ & $\begin{array}{l}\text { Genotype } \\
\text { frequency \% }\end{array}$ & $\begin{array}{c}\text { Serum iron } \\
(N V: 50-150 \mu \mathrm{g} / \mathrm{dl})\end{array}$ & $\begin{array}{c}\text { Transferrin saturation } \\
\text { (NV: } 20-50 \%)\end{array}$ & $\begin{array}{l}\text { Ferritin concentration } \\
(\mathrm{NV}: 15-300 \mu \mathrm{g} / \mathrm{dl})\end{array}$ & $\begin{array}{c}\text { Haemoglobin } \\
(\mathrm{N} 12-16 \mathrm{~g} / \mathrm{dl})\end{array}$ \\
\hline $\begin{array}{l}\text { C282Y Homozygous } \\
(n=1) \\
\text { C282Y Heterozygous } \\
(n=9) \\
\text { H63D Homozygous } \\
(n=4) \\
\text { H63D Heterozygous } \\
(n=35) \\
\text { Wild type } \\
(n=102)\end{array}$ & $\begin{array}{l}4.7 \\
2.7\end{array}$ & $\begin{array}{c}83 \\
(n=1) \\
140 \pm 56 \\
(n=9) \\
172 \pm 54 \\
(n=4) \\
122 \pm 37 \\
(n=32) \\
116 \pm 40 \\
(n=102)\end{array}$ & $\begin{array}{c}79 \\
(n=1) \\
42 \pm 10 \\
(n=6) \\
39 \pm 13 \\
(n=4) \\
31 \pm 89 \\
(n=27) \\
23 \pm 6 \\
(n=24)\end{array}$ & $\begin{array}{c}400 \\
(n=1) \\
139 \pm 104^{*} \\
(n=7) \\
77 \pm 8 \\
(n=4) \\
79 \pm 8 \\
(n=35) \\
63 \pm 67 \\
(n=102)\end{array}$ & $\begin{array}{c}14.06 \\
(n=1) \\
14.3 \pm 1.1 \\
(n=9) \\
14.5 \pm 1.1 \\
(n=4) \\
14.7 \pm 1.0 \\
(n=35) \\
13.4 \pm 1.2 \\
(n=102)\end{array}$ \\
\hline
\end{tabular}

Results are expressed as mean \pm standard deviation. NV: normal values; in brackets the number of individuals, ${ }^{*} P<0.01 v s \mathrm{H} 63 \mathrm{D}(\mathrm{OM}+\mathrm{HZ})$ and healthy individuals.

$(22.5 \%)$ showed, however, an iron storage depletion $(P: 0.0016)$.

The transferrin saturation was $23 \pm 6 \%$ in normal individuals, and $35 \pm 13 \%$ in HFE gene mutations carriers. Although these data were available only in a limited number of cases, the statistical analysis showed a significant difference between the two groups $(P<0.007)$. Details of the iron indices and HFE mutations are indicated in Table 1.

\section{HFE genotype and iron metabolism}

Considering the fact that the members of our population had undergone recurrent phlebotomies, their iron indices indicate the steady state between iron intake and iron loss. In fact, the frequency of phlebotomies is generally determined on the basis of haemoglobin concentration and iron or ferritin serum levels. Individuals showing low haemoglobin levels were excluded from donating blood, while those showing low iron or ferritin levels were asked to take oral iron supplements. In order to investigate the link between the frequency of the phlebotomies and the serum ferritin levels, we assumed that: (1) the mean dietary iron intake in 18 -60-year-old males is $16 \mathrm{mg} / \mathrm{day}$, of which one-tenth is absorbed by the intestinal mucosa $(1.6 \mathrm{mg})$, while the daily need is $1.0 \mathrm{mg}$. Therefore, in normal males the small iron loss is evened out by the iron absorbed and stored in the body (approximately $220 \mathrm{mg}$ / year); (2) each phlebotomy removes between 200 and $240 \mathrm{mg}$ of iron.

We were able to calculate for each patient the amount of iron stored and removed over a certain period, as well as the final iron balance (positive or negative). This was achieved by using simple parameters: the number of phlebotomies and the number of years since the first phlebotomy.

Unfortunately, this procedure cannot be adopted for females, as women need a greater iron intake ( $2 \mathrm{mg} /$ day); the iron balance is generally negative, even without phlebotomies. The female blood volunteers were asked at all times to take an oral iron compound. They were excluded from this analysis, as it was not possible to determine the amount and the time span of the iron-containing drug intake for each case.

According to the above-reported parameters, the male patients without HFE gene mutations showed that the mean iron removed was $4078 \pm 1665 \mathrm{mg}$, with a positive iron balance of $73.9 \pm 146.8 \mathrm{mg}$. The individuals with one or more HFE gene mutations showed a similar amount of removed iron $(5220 \pm 3110 \mathrm{mg})$ with a negative iron balance $(-63 \pm 277 \mathrm{mg})$. Despite the negative iron balance, the mean serum ferritin level in individuals with HFE gene mutations was still within a normal range $(108 \pm 105 \mu \mathrm{g} / \mathrm{l})$, although significantly higher than the level found in normal individuals $(61 \pm 29 \mu \mathrm{g} / \mathrm{l}, P<0.05)$. These findings can be explained only by assuming that HFE gene mutation carriers have an increased iron absorption.

\section{Population analysis}

We have considered the surname distribution, transmitted down the male line, as a neutral marker of a genetic locus, as foreseen by Piazza et al. ${ }^{25}$ This allows us, by use of the KarinMcGregor theory and the logarithmic distribution by Fisher, to obtain the migration rates $(v)$. The density of a surname $(\alpha)$ can be calculated as follows: $\alpha=\mathrm{N}^{*} v / 1-v$.

In our sample, $\alpha$ was 65.5 , when we considered the total male population, but, when analysing only males with all grandparents from Asiago, it became 34.7. The $v$ values were respectively 0.019 and 0.0105 .

\section{Discussion}

Several studies have already recorded the prevalence of HFE mutations in Italian blood donors, living mainly in large cities of Northern Italy, ${ }^{26}$ and in several Italian high-risk groups. ${ }^{21,22,27-29}$ The latter studies confirmed that the C282Y and H63D mutations are responsible for the majority of cases of haemochromatosis in Italy. Former studies have shown that the HFE gene mutations are more frequent in Northern Italy than in the south, ${ }^{30}$ as they are also evident in most western countries. Unfortunately, most studies did not 
include a detailed questionnaire regarding ethnic background or other demographic information. Epidemiological studies are difficult to carry out because of the high rate of immigration from the south to the major Northern Italian cities, particularly after the Second World War.

In 1980, Simon et al. ${ }^{12}$ stated that haemochromatosis has a Celtic origin. More recently, various papers confirmed a high prevalence of HFE gene mutations in populations of Celtic ancestry. ${ }^{31}$ The Celts colonised the western and central part of Southern Europe since 1000 B.C. Settlements then expanded towards Belgium, the UK, Ireland, France, ${ }^{32}$ Spain, ${ }^{33}$ Austria, Germany, ${ }^{34}$ Denmark ${ }^{35}$ and Eastern Europe. Around 400 B.C. the Celts settled in Northern Italy (called Gallia Cisalpina). The Cimbri, a Celtic tribe originating from Denmark, settled on the Asiago plateau, the Celts were defeated by the legions of the Roman Republic (and later Empire) in the centuries that followed, but, thanks to their favourable position, they had the opportunity to preserve their independence and ethnic integrity. The Asiago plateau kept a formal independence from the succeeding governments even during the Middle Ages, the Renaissance, the Republic of Venice, and the Austrian-Hungarian Empire. Most residents of Asiago can still be considered today Celtic, even though it was only after the First World War that immigrants began settling from the south of Italy.

The prevalence of the HFE gene mutations in Asiago is the highest among those recorded in Italy; it is quite similar to data of a study performed in Denmark (the ancient fatherland of the Cimbri), ${ }^{35,36}$ as shown in Table 2. A deeper analysis on the subgroup consisting of individuals with all grandparents from Asiago confirmed a higher frequency of HFE mutations. Several authors reported that surname analysis can provide interesting information on the genetic population structure. ${ }^{37-41}$ In the selected Asiago population, the analysis of surnames confirmed a lower migration rate than in those with at least one grandparent coming from elsewhere.

This study confirms that the HFE gene mutations are markers of people with a Celtic origin, as previously reported. ${ }^{30-32}$ As a matter of fact, our study confirms that the $\mathrm{C} 282 \mathrm{Y}$ mutation belongs to the Celtic extended haplotype together with HLA-A3 and D6S105 allele 8 . The great expansion of that ancient people can be explained (apart from several social and economical factors) by the widespread presence of these HFE gene mutations. This gave them selective advantages because their diet consisted mainly in iron-poor grains and cereals, whereas meat was highly uncommon. Furthermore, since the HFE gene is also expressed in the human placenta, ${ }^{42}$ one theory could be that a larger amount of iron can be transferred from the mother's blood, reducing perinatal mortality and morbidity in newborns.

Our results raise issues regarding the possibility (and usefulness) of performing large epidemiological studies to verify the prevalence of haemochromatosis in the general population. ${ }^{43-45}$ On the basis of our data and that of other authors, the screening should be limited to the population of Celtic ancestry, ie Northern Italy. An additional problem is how to perform the screening: on the basis of genetic tests or on serum iron measurements? ${ }^{46}$

The use of serum iron measurements is affordable and able to identify some 80 to $90 \%$ of affected patients, but it is not able to identify the intermediate stages of the disease when the iron overload has not yet been established. On the other hand, genetic tests, even though much more expensive, are able to identify the individuals who might develop the disease. We believe genetic testing to be of greater use, because it enables prevention of the disease. Once the iron overload is established, repeated phlebotomies are not always able to remove the excess iron, nor can they improve the already present heart damage.

Therefore, before establishing the diagnosis on the basis of iron parameters or liver biopsy, we must act upon an iron overload prevention and not upon iron storage, especially when organ damage has already been established.

Despite the high frequency of HFE gene mutations in our population, no patient has yet shown iron indices to be consistent with those of the haemochromatosis, nor did homozygous cases (one for $\mathrm{C} 282 \mathrm{Y}$ and four for H63D) show iron storage (this is due to the fact that each case underwent the recommended phlebotomy treatment). Therefore, the common iron indices are not useful in detecting potential haemochromatosis carriers in blood donors. To overcome this problem, we suggest calculating (as shown in the Results section) the iron balance for each patient. If, despite a normal serum ferritin level, the balance is negative, the subject could be a carrier of the HFE gene mutations.

Table 2 Frequencies of HFE gene mutations in a Danish population ${ }^{35}$ and in our population of Celtic ancestry

\begin{tabular}{lccc}
\hline HFE mutations & $\begin{array}{c}\text { Danish }(\mathrm{n}=200) \\
(\%)\end{array}$ & Cimbri $(\mathrm{n}=149)$ & $(\%)$ \\
\hline C282Y homozygous & 0.5 & 0.7 & $\mathrm{NS}$ \\
C282Y heterozygous & 13.5 & 4.7 & $<0.7$ \\
H63D homozygous & 1.5 & 2.7 & $\mathrm{NS}$ \\
H63D heterozygous & 22.5 & 23.5 & $\mathrm{NS}$ \\
\hline
\end{tabular}

As shown, the prevalance of the gene mutations is quite similar in the two populations. A significantly higher prevalence of C282Y heterozygous has been found in the Danish population. NS: not significant. 
In conclusion, this study indicates that the prevalence of HFE gene mutations is surprisingly high in Italians of Celtic ancestry. This could indicate the need to perform large mass studies in selected areas of the country ${ }^{47}$ in order to detect affected patients and, more importantly, to prevent the development of the disease in carriers of the gene mutation. Traditional DNA tests are used in screening, as was done in this study. However, since standard genetic tests are rather expensive, our laboratories have recently developed a new effective low cost method for the detection of main HFE gene mutations, using a melting temperature assay. ${ }^{48}$

\section{Acknowledgements}

This study was partly supported by MURST 40\% and 60\% projects, and, by IRCCS Burlo Garofolo 'progetto ricerca corrente' $n$. 19/99. Serena Vatta is the recipient of a fellowship from IRCCS Burlo Garofolo, Trieste. We are indebted to Dr Armanda Diamantini and Dr Carla Giordano of the Transfusion Centre of Bassano for providing the blood donors' samples. We thank Bruce Dangerfield PhD (Rush Cancer Institute, 2242 W. Harrison St., Chicago, IL 60601-3515) for reviewing the manuscript and for the helpful discussion. The authors are greatly indebted to Nicole Bolzicco for her collaboration in the preparation of this manuscript.

\section{References}

1 Bassett ML, Halliday JW, Brittenham GM: Genetic haemochromatosis. Sem Liver Dis 1994; 4: 217-227.

2 Niederan C, Fischer R, Sonnenberg A: Survival and cause of death in cirrhotic and non cirrhotic patients with primary haemochromatosis. N Engl J Med 1985; 313: 1256-1262.

3 Bodmer JG, Parham P, Albert ED, Marsh SG on behalf of the WHO Nomenclature Committee for Factors Of the HLA System: Putting a hold on 'HLA-H'. Nat Genet 1997; 15: 234-235.

4 Feder JN, Gnirke A, Thomas W et al: A novel MHC class I-like gene is mutated in patients with hereditary haemochromatosis. Nat Genet 1996; 13: 399-408.

5 Waheed A, Parkkila S, Yan Zhou X et al: Hereditary hemochromatosis: Effects of $\mathrm{C} 282 \mathrm{Y}$ and $\mathrm{H} 63 \mathrm{D}$ mutations on association with $\beta_{2}$ microglobulin, intracellular processing, and cell surface expression of the HFE protein in COS-7 cells. Proc Natl Acad Sci USA 1997; 94: 12384-12389.

6 Beutler E, Gelbart T, West C et al: Mutation analysis in hereditary hemochromatosis. Blood Cells Mol Dis 1996; 22: 187-194.

7 Pietrangelo A, Montosi G, Totaro A et al: Hereditary hemochromatosis in adults without pathogenic mutations in the hemochromatosis gene. N Engl J Med 1999; 341: 725 - 732.

8 Orlandi E, Arbustini E, Lazzarino M: Isolated hyperferritinemia with normal transferrin saturation and dysmetabolism, in the absence of the two known mutations in the HFE gene of hereditary hemochromatosis. Haematologica 1999; 84: 181182.

9 Edwards CQ, Dadone MM, Skolnick MH, Kushner JP: Hereditary hemochromatosis. Clin Haematol 1982; 11: 411 - 435.

10 Edwards CQ, Griffen LM, Goldgar D, Drummond C, Skolnick $\mathrm{MH}$, Kushner JP: Prevalence of hemochromatosis among 11,065 presumably healthy blood donors. $N$ Engl J Med 1988; 318: $1355-1362$.

11 Legget BA, Halliday JW, Brown NN, Bryant S, Powell LW: Prevalence of haemochromatosis among asymptomatic Australians. Br J Haematol 1990; 74: 525 - 530.

12 Simon M, Alexandre JL, Fauchet R, Genetet B, Bourel M: The genetics of hemochromatosis. Prog Med Genet 1980; 4: 135-168.
13 Karlsson M, Ikkala E, Reunanen A, Takkunen H, Vuori E, Makinen J: Prevalence of hemochromatosis in Finland. Acta Med Scand 1988; 224: 385 - 390.

14 Hallberg L, Bjorn-Rasmussen E, Jungner I: Prevalence of hereditary hemochromatosis in two Swedish urban areas. Intern Med 1989; 225: 249-255.

15 Jonsson JJ, Johannesson GM, Sigfusson N, Magnusson B, Thjodleiffson B, Magnusson S: Prevalence of iron deficiency and iron overload in the adult Icelandic population. $J$ Clin Epidemiol 1991; 44: 1289-1297.

16 Velati C, Piperno A, Fargion S, Colombo S, Fiorelli G: Prevalence of idiopathic hemochromatosis in Italy: study of 1301 blood donors. Haematologica 1990; 74: 525-530.

17 Piperno A, Fargion S, D'Alba R et al: Liver damage in Italian patients with hereditary hemochromatosis is highly influenced by hepatitis B and C virus infections. J Hepatol 1992; 16: $364-$ 368.

18 Sohda T, Yanai J, Soejima H, Tamura K: Frequencies in the Japanese population of HFE gene mutations. Biochem Genet 1999; 37: 63-68.

19 Chang JG, Liu TC, Lin SF: Rapid diagnosis of the HLA-H gene Cys 282 Tyr mutation in hemochromatosis by polymerase chain reaction: a very rare mutation in the Chinese population. Blood 1997; 89: $3492-3493$.

20 Piperno A, Arosio C, Fargion S et al: The ancestral hemochromatosis haplotype is associated with a severe phenotype expression in Italian patients. Hepatology 1996; 24: 43- 46.

21 Conte D, Manachino D, Colli A et al. Prevalence of genetic hemochromatosis in a cohort of Italian patients with diabetes mellitus. Ann Intern Med 1998; 128: 370-373.

22 Fargion S, Fracanzani AL, Romano R et al: Genetic hemochromatosis in Italian patients with porphyria cutanea tarda: possible explanation for iron overload. J Hepatol 1996; 24 $564-569$.

23 Roberts AG, Whatley SD, Morgann RR, Worwood M, Elder GH: Increased frequency of haemochromatosis Cys282Tyr mutation in sporadic porphyria cutanea tarda. Lancet 1997; 349: 321 323.

24 Weber JL, Kwitek AE, May PE, Zoghbi HY: Dinucleotide repeat polymorphism at the D6S105 locus. Nucleic Acids Res 1991; 19: 968.

25 Piazza A, Rendine S, Zei G, Moroni A, Cavalli-Sforza L: Migration rates of human populations from surname distributions. Nature 1987; 329: $714-716$.

26 Gomez A, Sbaiz L, Bertino E et al: Screening of the C282Y mutation in the HFE gene in Italy by Taqman technology. Proceedings of BioIron99, Sorrento, Italy; May 23-28, 1999; 238 (abstract).

27 Cassanelli S, Pignatti E, Montosi G, Garuti C, Pietrangelo A: Prevalence of HFE mutations in 2,000 presumably healthy blood donors in Italy. Proceedings of BioIron99, Sorrento, Italy; May 23-28, 1999; 249 (abstract).

28 Velati C, Marlianici E, Rinaldi S et al: Screening in blood donors for hereditary hemochromatosis (HH) in Italy. Proceedings of BioIron99, Sorrento, Italy; May 23 - 28, 1999; 237 (abstract).

29 Belloli S, Ruggeri G, Facchinetti D, Arosio P, Radaeli E, Albertini A: Prevalence of $\mathrm{C} 282 \mathrm{Y}$ and H63D mutations of HFE in iron overloaded individuals in Brescia. Proceedings of Biolron99, Sorrento, Italy; May 23-28, 1999; 244 (abstract).

30 De Marco F, Giardina MG, Matarazzo M et al. Occurrence of HFE $\mathrm{C} 282 \mathrm{Y}$ and H63D mutations in patients with hereditary hemochromatosis from southern Italy. Proceedings of BioIron99, Sorrento, Italy; May 23-28, 1999; 246 (abstract).

31 Smith BN, Kantrowitz W, Grace ND et al: Prevalence of hereditary hemochromatosis in a Massachusetts Corporation: is Celtic origin a risk factor? Hepatology 1997; 25: 1439-1446.

32 Jouanolle AM, Fergelot P, Raoul ML et al: Prevalence of the C282Y mutation in Brittany: penetrance of genetic Hemochromatosis ? Ann Genet 1998; 41: 195 - 198. 
33 Fabrega E, Castro B, Sanchez-Castro L, Benito A, FernandezLuna JL, Pons-Romero F: The prevalence of the Cys282Tyr mutation in the hemocromatosis gene in Cantabiria in patients diagnosed with hereditary hemochromatosis. Med Clin (Barc) 1999; 112: $451-453$.

34 Nielsen P, Carpinteiro S, Fischer R, Cabeda JM, Porto G, Gabbe EE: Prevalence of the C282Y and H63D mutations in the HFE gene in patients with hereditary haemochromatosis and in control individuals from Northern Germany. Br J Haematol 1998; 103: $842-845$.

35 Steffensen R, Varming K, Jersild C: Determination of gene frequencies for two common haemochromatosis mutations in the Danish population by a novel polymerase chain reaction with sequence-specific primers. Tissue Antigens 1998; 52: 230 235.

36 Wiggers P, DalhØj J, Kiaer H et al: Screening for haemochromatosis: prevalence among Danish blood donors. J Intern Med 1991; 230: $265-270$.

37 Zei G, Guglielmino-Matessi R, Siri E, Moroni A, Cavalli-Sforza L: Surnames in Sardinia. I. Ann Hum Genet 1983; 47: 329-352.

38 Zei G, Piazza A, Moroni A, Cavalli-Sforza L: Surnames in Sardinia III. Ann Hum Genet 1987; 50: $169-180$.

39 Crow JF, Mange AP: Measurement of inbreeding from the frequency of marriages between persons of the same surname. Eugen Quart 1965; 12: 199 - 203.

40 Lasker GV: Increments through migration to the coefficient of relationship between communities by isonymy. Hum Biol 1978 50: $235-240$.
41 Yasuda N, Cavalli Sforza L, Skolnick M, Moroni A: The evolution of surnames: an analysis of their distribution and extinction. Theor Pop Biol 1974; 5: 123 - 142.

42 Parkkila S, Waheed A, Britton RS et al: Association of the transferrin receptor in human placenta with HFE, the protein defective in hereditary hemochromatosis. Proc Natl Acad Sci USA 1997; 94: 13198-13202.

43 Burt MJ, George PM, Upton JD et al. The significance of haemochromatosis gene mutations in the general populations: implications for screening. Gut 1998; 43: 830-836.

44 Cogswell ME, Burke W, McDonnell SM, Franks AL: Screening for hemocromatosis. A public health perspective. Am J Prev Med 1999; 16: $134-140$.

45 Charvet-Protat S, Yaounang J, Fleurette F: Should we screen for Hemochromatosis? Critical analysis of the literature. Rev Epidemiol Sante Publique 1997; 45: 315 - 327.

46 Phatak PD, Guzman G, Woll JE, Robeson A, Phelps CE: Costeffectiveness of screening for hereditary hemochromatosis. Arch Intern Med 1994; 154: 769 - 776.

47 Burke W, Thomson E, Khoury MJ et al: Hereditary hemochromatosis: gene discovery and its implications for populationbased screening. JAMA 1998; 280: 172-178.

48 Marziliano N, Bevilacqua E, Pirulli D, Spanò A, Amoroso A, Crovella S: A single tube melting temperature assay for rapid and sensitive detection of $\mathrm{C} 282 \mathrm{Y}$ and $\mathrm{H} 63 \mathrm{D}$ most frequent hemocromatosis mutations. Haematologica 2000; 85: 985 - 986. 